The American Journal of Agriculture and Boimedical Engineering (ISSN - 2689-1018)

Published: November 30, 2020 | Pages: 42-46

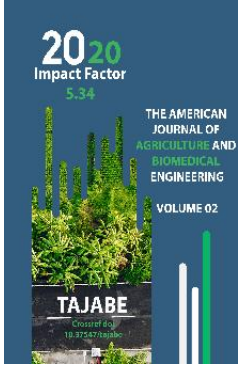

\title{
The Peach Propagation Methods
}

Hamidakhon Komiljonovna Khatamova

Assistant, Andijan Institute Of Agriculture And Agro-Technology, Uzbekistan

Kholida Azamovna Kimsanova

Assistant, Andijan Institute Of Agriculture And Agro-Technology, Uzbekistan

Copyright: Original

content from this work may be used under the terms of the creative commons attributes 4.0 licence.

\section{ABSTRACT}

To provide the population with quality fruits throughout the year, to learn ways to effectively propagate peach fruits.

\section{KEYWORDS}

Peach, graft, green cuttings, healing, quality, tour and new.

\section{INTRODUCTION}

As the population of our country grows, the demand for food is growing day by day. On the basis of intensive technology, gardens are being established and various fruits are being grown.

The Agricultural Research and Production Center of Uzbekistan have developed a comprehensive program of measures for the further development of research in the field of fruit and vegetable growing and viticulture in 2017-2021.

The program sets tasks such as modernization of the material and technical base of laboratory buildings of scientific institutions specializing in horticulture, viticulture and vegetable growing on the basis of state and foreign grants, development of selection work, creation of promising fruit varieties and construction of warehouses. 
In order to further develop horticulture and viticulture in our country, great attention is paid to the creation of gardens on the basis of intensive technology. Pear, apricot, plum, peach, cherry and apple orchards are popular with many because of their fast yield and high yield. Intensive orchards of walnuts, figs and dates have also been established, proving that a bountiful harvest can be obtained.

\section{THE MAIN FINDINGS AND RESULTS}

According to the Ministry of Agriculture and Water Resources of the Republic of Uzbekistan, targeted programs have been developed to expand intensive orchards. Today, such gardens have been established on 32,400 hectares in our country. This year, another 13,000 hectares of intensive gardens will be planted.

Peaches are distinguished by their whimsy and healing properties.

Peach trees bear fruit early, yield abundantly every year, the fruit is very beautiful, the trees grow vigorously, but are more resistant to cold than other legumes. Peach trees can yield up to $100-150 \mathrm{~kg}$ in 3-4 years after planting. It is not difficult to care for and harvest small branches. Peach varieties ripen from June to November, thus extending the supply of peach fruit to 5 months. The fruit is juicy, sweet, unobtrusive, soothing and very tasty. It is eaten fresh, as well as jams, compotes and various pickles. Peaches are quickly assimilated by the human body; they are rich in various vitamins, mineral salts and are useful in building hemoglobin.

Peaches are very common and can be successfully grown in many regions of Uzbekistan. For good development of peaches requires adequate watering in the summer, fertile and moisture-permeable and nitrogen-rich soil, as well as thinning of the fruit, as well as the use of chemicals against peach leaf rot and moniliosis.
Peach tree has a short lifespan (15-20 years). Peaches (including hairless species) do not need a pollinating tree because they can fertilize themselves.

Demand for soil. Peach trees prefer soils with a partial $\mathrm{pH}$ (amount of hydrogen ions in the soil) slightly higher than 6.0 and 6.5. A tree can grow even if this figure is a little more or less. But such conditions have a negative impact on his health and productivity. Peach trees grow well in sandy and water-permeable soils. If the water permeability of the soil is poor, it is recommended to add manure, sand or peat (plant humus) and mix it into a deep chisel. It is not recommended to put the above-mentioned products to improve the soil composition in the pit where the seedlings are planned to be planted.

The roots of peach trees die in well-drained soils, stop growing and die.

Most fruit trees grow well in conditions where the $\mathrm{pH}$ of the soil is close to 6.5. Due to the high $\mathrm{pH}$ of the soil in most parts of Uzbekistan, it is possible to normalize its $\mathrm{pH}$ by adding gypsum before planting.

Demand for water. The peach tree consumes the most water during its youth - it is recommended to water the annual seedlings once a week or in summer, twice a week. According to the recommendation of Steve Albert, Senior Gardener at the University of California, fruit trees will be more productive when the soil is kept moist enough. A peach tree can bear fruit even in the absence of water, but the tree is in a state of stress and the fruits remain small. Mulch (crushed plant and tree debris) is placed around the trunk to retain soil moisture, but the mulch should not touch the trunk.

Fertilization procedure. Fertilization at the right time is very important for the developing (active) nutrient supply roots to absorb nutrients. It is not recommended to fertilize peach seedlings planted during the dormant 
period from mid-winter to March, until August. Apply 1 cup (250gr) of fertilizer, ammonium sulfate or calcium nitrate around the trunks of biennial or fully developed trees in June-August. But prevent the feed from accumulating near the trunk. In each season, in early March, apply a complex fertilizer in the formula "NPK 10-10-10" around the trunk. This fertilizer contains more than 10\% nitrogen, phosphorus and potassium. Follow the instructions on the fertilizer container. Excessive use of fertilizers can negatively affect fruit quality and reduce next year's yield.

Peach trees thrive in nitrogen-rich soils, and the nutrients they need in the first place include elements such as nitrogen, calcium, phosphorus, magnesium, sulfur, and potassium. Although these nutrients are present in the soil to a certain extent, laboratory analysis of the soil can help determine the extent of their presence and deficiency. Less commonly needed nutrients include chlorine, iron, manganese, boron, copper, zinc, and molybdenum.

Peach (Regasa) is a fruit tree belonging to the genus Regasa. Homeland - Central Asia, 6 species are known. Six types include: common peach, gansun peach, David peach, potanin peach, myr peach, Fergana peach is common in the USA, southern Europe, Japan, China, Turkey, Central Asia and Transcaucasia.

Peaches were cultivated 2,000 years ago and there are about 5,000 varieties. Today, peaches are grown in all subtropical and tropical countries of the Southern Hemisphere. It is the third largest fruit tree in Uzbekistan.

In Uzbekistan, mainly peach varieties such as Lola, Elberta, Raspberry, Start, Farkhod and Uchkun are recommended for planting.

Peaches are propagated by seeds and grafted. Today, there are several methods of propagation of peaches, propagation by cuttings, propagation by bud grafting and propagation by green cuttings forming a mist.

Today, technologies for the cultivation of indoor root system planting materials in containers, winter welding, the use of polymers and other materials for mulching the soil, propagation of green cuttings have been developed for production conditions. Mechanization is widely used - many processes are automated. As a result, it will be possible to perform the above-mentioned and many other tasks in the off-season. Most of the work is carried out in industrial facilities equipped with the necessary equipment.

Green pruning technology ensures a much faster and more efficient production of fruit and berry crops. As a result of the use of modern means of mechanization and automation of labor-intensive processes, green cutting technology has gained an industrial basis. Many works in nurseries are mechanized with the help of serially produced machines and units. Humidification of the cuttings with a mist-forming device and the substrate temperature regime are automatically controlled using software control. Feeding the cuttings with solutions of mineral fertilizers is also carried out using an automated artificial fog system. The development of special designs of automatic devices and mechanical knives for cutting cuttings and simultaneous planting of cuttings in containers allows not only mechanization, but also automation of many labor-intensive processes.

Green cutting technology has a number of other advantages in addition to a high degree of mechanization and automation. Green pruning is carried out in a protected area. The cultivation of planting material is less dependent on climatic conditions.

For green pruning use cuttings of 5-12 cm of the branch and a shorter one-leaf and singleleaf (leaf-bud cuttings) - 2-3 cm. Recently, 
cuttings of $25-40 \mathrm{~cm}$ are being used. Rooted cuttings in this way gave a much more developed plants in the fall. It is possible to make a lot more green cuttings than a single mother bush that has been turned into wood and parsnips. For example, the mother of cloned grafts of apples does not give more than 100-120 thousand parsnips. From green cuttings it is possible to get $500-600$ thousand per hectare. As a result of the increase in the number of cuttings prepared from a single bush, the area of maternal crops can be reduced by four to five times.

It is possible to get 1 million rooted cuttings from 1 ha of greenhouse area by turning them once. Accordingly, depending on the variety, such production cycles may be two or three. Thus, intensive use of the greenhouse area makes pruning technology highly profitable. The cost of building a greenhouse and microclimate-creating equipment will be recouped in two years.

Green pruning allows you to get rooted plants on their own. The peculiarity of such plants is that genetic homogeneity, physiological and anatomical integrity of the organism is preserved. Self-rooted plants have the ability to self-regenerate when the surface is destroyed. This is especially important for crops with low winter hardiness.

Green cuttings help the rooting of cuttings of many plant species that cannot reproduce vegetatively using other methods; allows you to expand the number of crops and varieties that are capable of vegetative reproduction. It has no equal for the rapid proliferation of forms that are present in small numbers in maternal copies. These are valuable plants created by breeders or individual plants obtained as a result of disinfection from viral, mycoplasmal and other diseases and pests. Green cuttings help to heal crop material. Growing twigs are less affected by agricultural pests (steklyannitsa, gallitsa) by the time of pruning than woody twigs.
Cuttings prepared from an active growth zone and grown under sterile conditions can produce plants that are not infected with viruses. Thus, pruning black currants allows you to get a clean crop material from the bud canal. The bud canal is a carrier of reversion (layering). It is a more common dangerous mycoplasma disease, which reduces the yield of black currants by up to $50 \%$ and leads to infertility of the plant.

The prospects for green cuttings are expanding due to its combination with other methods of plant propagation. With the help of green cuttings can be grown not only plants that have their own roots, but also grafted plants. For some crops it is carried out by pruning, pruning of woody twigs, pruning peach rosettes. This increases the growth of seedlings per unit area. Labor organization will be improved, the workforce will be evenly distributed, and this will have a positive impact on economic performance.

\section{CONCLUSION}

Today in our country the biological basis of green cuttings is widely studied, the technology is identified and improved, taking into account the specifics of regional conditions.

The experiment will involve 2-3 promising grafts of peaches, which are being studied for grafting regionalized varieties of peaches in the Republic. The grafts are planted in the nursery in a 70x20 scheme. Each variant of the experiment is presented with 100 welds. The experiment is repeated four times. In total, 400 grafts will be planted in each option.

\section{REFERENCES}

1. Sobirov M. Q. (1991) "Horticulture". Tashkent. 
The American Journal of Agriculture and Boimedical Engineering (ISSN - 2689-1018)

Published: November 30, 2020 | Pages: 42-46

Doi: https://doi.org/10.37547/tajabe/Volumeo2Issue11-08

2. H. Buriev and R. Rizaev (1996) "Biochemistry and technology of fruit and grape products". - Tashkent.

3. https://agro-olam.uz/shaftoli-navlari-vaularni-yetishtirish-boyicha-tavsiyalar/

4. http://www.agro.uz/uz/services/useful/78 $46 /$

5. https://youtu.be/7olkgCp5du4 